\title{
Career Growth Opportunity on Turnover Intention: The Mediating Role of Organizational Commitment in Multinational Corporations
}

\author{
Joonghak Lee \\ Dongguk University, Republic of Korea \\ E-mail: glc.hak@gmail.com \\ Steven B Kim \\ California State University, Monterey Bay, United States \\ E-mail: stkim@csumb.edu \\ Chungil Chae \\ Pennsylvania State University \\ E-mail: chaechae@gmail.com
}

Jaeeun Lee

Konkuk University, Republic of Korea

E-mail: violet80119@gmail.com

Received: Aug. 9, 2019 Accepted: Sep. 3, 2019 Online published: Sep. 11, 2019

doi:10.5296/ijhrs.v9i4.15245 URL: https://doi.org/10.5296/ijhrs.v9i4.15245

\begin{abstract}
In accelerated globalization, multinational corporations (MNCs) continually seek opportunities to expand their businesses to foreign countries. For sustainable businesses in foreign countries, it is important to retain a large number of local employees which is challenging. Based on existing literature in international human resource management, we
\end{abstract}


hypothesized that organizational commitment (OC) is a mediator in the relationship between perceived career growth opportunity (CGO) and turnover intention (TO) among local employees in MNCs. We analyzed a sample from five companies affiliated with a Korean MNC located in Vietnam. From the mediation analysis, it was evident that OC is a partial mediator between CGO and TO. In particular, CGO and OC were positively correlated, OC and TO were negatively correlated, and CGO and TO were still negatively correlated when OC was adjusted in the regression model. These findings provide a new insight in the field of international human resource in growing MNCs.

Keywords: perceived growth opportunity, turnover intention, organizational commitment, international human resource management

\section{Introduction}

In accelerated globalization, multinational corporations (MNCs) continually seek opportunities to expand their businesses to foreign countries. The rapid expansion of international trade and foreign investment has increased the demand for highly skilled managers and professionals particularly in Asian countries (Zheng \& Lamond, 2009). In order to expand businesses to Asian countries, MNCs are aware of the importance of hiring competitive employees in the marketplace, and a large number of local employees have been hired (Carmeli, 2004). In MNCs, important factors in human resource management (HRM) are adaptation to host countries, utilization of dispersed workforces, and coordination of overseas HRM operations (Chung \& Furusawa, 2015, Rosenzweig, 2006). These are critical factors to fully utilize available resources and to take advantage of the large scale of MNCs.

MNCs face significant challenges in local markets such as cultural difference, regional economic disparity, insufficient managerial talent, and distinct consumer behavior (Fayol-Song, 2011). An opinion poll from HRM professionals in Hong Kong, Malaysia and Singapore showed a unanimous view that "job hopping" has become a culture in these countries (Khatri, Fern, \& Budhwar, 2001). Furthermore, job hopping has been regarded as an Asian employee's attitude (Khatri, Fern, \& Budhwar, 2001). There have been numerous reports which support the continuing trend of frequent employee turnovers. It is due to a consequence of the increasing volume of trade and investment as well as a greater degree of freedom in skilled labor migration in the region ( $\mathrm{Li}, 2008)$. Also, the turnover of employees has always been an important concern for organizations, regardless of their sizes, locations, business strategy or natures of business (Al-khrabsheh, Abo-Murad, \& Bourini, 2018).

Internationally, employee retention faces additional challenges, both with regard to the scope of turnover determinants and the applicability of specific retention-oriented HRM practices (Reiche, 2008). The use of expatriates frequently entails high pay differentials between local staffs and assignees, and it can be perceived against distributive justice by the local staffs (Toh \& DeNisi, 2003). Harzing (2001) found that $79.5 \%$ of subsidiary managing directors were host country nationals for American MNCs, while the percent was $40.7 \%$ and $37.5 \%$ for German MNCs and Japanese MNCs, respectively. In that sense, MNCs cannot overlook fair compensation between expatriates and local employees to retain local employees. In addition, long-term retention also requires fair employee treatment. Distributive justice concerns the 
perceived fairness in compensation, and the procedural justice concerns fairness in promotion, transparency, and contribution to decision-making process. Both distributive justice and procedural justice are particularly salient for retention (Bloom \& Michel, 2002; Shaw, Delery, Jenkins, \& Gupta, 1998).

To our knowledge, there is little empirical-based research done on the turnover intention of local employees in MNCs based on internal factors such as career development and training opportunities. To better understand the turnover intention via perception of career growth opportunity and organizational commitment, we surveyed local employees in a MNC located in Vietnam. We analyzed the survey data to identify demographic variables associated with the turnover intention, and we explored the relationship among the turnover intention, perception of career opportunity, and organizational commitment.

\section{Literature Review and Hypotheses Development}

\subsection{Turnover Intention in MNCs}

As a result of growing internet and other communication technologies since the late 1990s (Hertel, Geister, \& Konradt, 2005), staffs do not relocate to a host location but have a responsibility to manage internationally staff from the home base (Dowling \& Welch, 2004). Hailey (1993) identified three sources of pressure prompting to localize personnel: local government, local managers, and the firm's parent company. First, local governments in some countries of the emerging market seek independence of MNCs management by introducing work permits, expatriate quotas, and financial audits of expatriate salaries. Second, as local employees gain work experience, they are likely to be dissatisfied with their secondary position since they cannot have career visibility due to their expatriates' managerial position. Third, parents' companies in host countries localize their management posts because of cost reduction and their accumulated knowledge in local management.

It is likely that the more dominant role played by expatriates to control local subsidiaries, the less important role would be taken by local managers (Harzing, 2001). According to social exchange theories, individuals enter into relationships with others to maximize their benefits (Blau, 1964; Homans, 1974). As local employees perceive a lack of opportunities for their career advancement (i.e., less opportunities to increase their own benefits), there might be a high level of turnover intention (Reiche, 2007). The social exchange theories also highlight the importance of understanding employees' motivation and its relation to the achievement of organizational goals (Aselage \& Eisenberger, 2003). These theories can explain employees' motivation for making organizational commitment to fulfill the mutual obligations between employees and employers, and a lack of such motivation may result in turnover intention.

\subsection{Relationship Between Perceived Career Growth Opportunity and Turnover Intention}

Arthur (2008) defined career as a sequence of work experiences during one's lifetime. The word "development" means growth, continuous acquisition, and application of one's skills, and "career development" refers to an ongoing process of planning and directed action toward personal work and life goals (Simonsen, 1997, p. 6). Kraimer, Seibert, Wayne, Liden, \& Bravo (2011) conceptualized perceived career opportunity as a belief that an employee's 
current position matches with one's career goals and interests in the organization. Their concept of perceived career opportunity is different from the concept of organizational support for development which refers to programs and opportunities provided by the organization to support employee's development. Employees can perceive a career growth opportunity (CGO) when assigned work and their visions match with their career interests and goals.

Many researchers have noted that the nature of careers has evolved rapidly due to various reasons (e.g., technology development, expanded knowledge bases, and emerging global competition), and they might be related to a shorter period of retention in an organization (Arthur, 2008; Chay \& Aryee, 1999; Granrose \& Baccili, 2006; Sturges, Guest, \& Davey, 2000). For example, core employees can be motivated to stay through instant provision of training and development programs that will increase their future employability in the firm (Coff, 1997).

In MNCs any gap between expatriates and local employees can affect perceived CGO. Substantial pay differentials between the two groups lead to frustrations and discouragement among local employees (Toh \& DeNisi, 2003). In addition, the nature of international staffing may negatively influence local employees' career visions and organizational identifications because they would feel that their opportunities are taken away. Turnover may be an outcome related to employee's career goals and opportunities, and the organization that promotes employees' perceived CGO may have a high retention rate (Maetz \& Campion, 2004). In particular, many MNCs have a gap between expatriates and local employees, and abundant CGO provided by these MNCs will be appreciated by its local employees. To this end, we hypothesize that perceived CGO is associated with lower turnover intention.

\subsection{Relationship Between Perceived Career Growth Opportunity and Organizational Commitment}

Organizational commitment (OC) has been a central concept in the study of work attributes and behaviors (Mathieu \& Zajac, 1990; Meyer \& Allen, 1997; Morrow, 1993; Reichers, 1985). It is broadly defined as a psychological link between an employee and the organization which reduces the chance of leaving the organization voluntarily (Allen \& Meyer, 1996).

Since OC is a key concept in the study of work attribute and behavior, the OC construct has played an increasingly important role (Morrow, 1993), and several approaches of the OC construct have been proposed. For more than two decades, three-dimensional scales have been a popular approach (Myer \& Allen, 1984; Myer \& Allen, 1997; Cohen, 2007). Meyer \& Allen (1991) refined multi-dimensionality of the OC into three distinct themes: affective, normative, and continuance commitment. Affective commitment is an employee's link to the organization (Fields, 2002). Normative commitment designates the feeling of obligation to continue the employment, and continuance commitment indicates the employee's awareness related to the cost associated with leaving the organization (Fields, 2002).

Factors which influence OC include personal characteristics, role-related variables, and work 
experiences. Personal characteristics consist of two types of variables, demographic and dispositional (Sinem \& Baris, 2011). Role related variables can influence the degree of OC by conflicts and stresses caused by uncertainty in the organization (Mathieu \& Zajac, 1990). A cross-level non-recursive (bidirectional) model indicated that commitment is reciprocally related with satisfaction, and the effect of satisfaction on commitment is stronger (Mathieu, 1991).

Unlike the economic exchange relation (between money and services) which often lasts for a short period of time, the social exchange relation provides feelings of personal obligation, gratitude, and trust which the economic exchange relation cannot provide (Blua, 1964). Researchers argued that an individual engages in social exchange relations in the workplace not only with other employees (e.g., supervisors) but also with the organization (Masterson, Lewis, Goldman, \& Taylor, 2000; Rupp \& Cropanzano, 2002).

According to the social exchange theory, career growth opportunities (CGO) motivate employees that they are valued and respected in their organizations (Cavanaugh \& Noe 1999). Researchers have studied the effect of CGO on employee's work attitude and behavior (Ito \& Brotheridge, 2005; Lee \& Bruvold, 2003). The CGO can be provided by various ways such as support from peers and supervisors, organizational policies, and programs designed for career development (Mauer \& Tarulli, 1994). In social exchange relations, CGO are recognized as an important benefit provided by the organization (Nouri, \& Parker, 2013). Furthermore, it has been widely accepted that institutionalized career planning and growth opportunities help employees bind to their institution (Coff, 1997; Mobley, 1982). To this end, it is sound to hypothesize that perceived career growth opportunity is positively associated with organizational commitment.

\subsection{Relationship between Organizational Commitment and Turnover Intention}

Over the last few decades, many researchers have studied turnover intention among employees (willingness to leave their organizations). Turnover intention is the most important antecedent of actual turnover (Oh et al. 2007), and it is based on the theory of planned behavior (TPB) which has been widely accepted by many scholars. Employees' turnover intention is of interest in diverse fields as it has been identified as an important factor for the financial performance of organizations (Lambert, Hogan, \& Barton, 2001; Joo \& Park, 2010). Huselid (1995) found that high-performance human resource practices are likely to increase individual productivity and decrease turnover intention.

It has been long believed that higher organizational commitment leads to greater effort, higher job satisfaction, better performance, and lower turnover (Randall, 1990; Mathieu \& Zajac, 1990; Meyer \& Allen, 1997; Riketta, 2002; De-Coninck \& Bachmann, 2011). Turnover is affected by attitude of workers (Alam \& Asim, 2019). Porter \& Steers (1973) claimed that work attitude (organizational commitment) and job satisfaction are the most influential factors to turnover intention, and a number of meta-analyses were performed to prove the relationship between work attitudes and turnover intention (Tett \& Meyer, 1993, Griffeth, Hom, \& Grartner, 2000). Historically, organizational commitment has received most attention because of its consistent relationship to turnover (Cohen, 1993), and retention has 
been regarded as an important consequence and a key predictor of organizational commitment (Arnold \& Feldman, 1982; Mowday, Koberg, \& McArthur, 1984; Hollenbeck \& Williams, 1986).

Organizational commitment is related to emotions, positive or negative, and unwillingness to withdraw from the target (Wright \& Kehoe, 2007). In the scope of MNCs, (Khatri, Fern, \& Budhwar, 2001) identified organizational commitment, procedural justice, and "job hopping" attitude as key factors of turnover in Asia based on their studies among 212 Singapore-based companies. Based on the abundant prior research, it is sensible to hypothesize a negative relationship between organizational commitment and turnover intention.

\subsection{Objective}

The level of organizational commitment is relatively low among local employees of MNCs because they do not see the corporate policies and procedures are not in favor of their career development (Zheng \& Lamond, 2010). To this end, we hypothesized that a lack of perception in their career growth opportunity causes low organizational commitment, and low organizational commitment causes high turnover intention based on the aforementioned studies. In other words, we believed that organizational commitment is a mediator of the relationship from perceived career growth opportunity to turnover intention, and our primary objective is to provide statistical evidence and quantify the strength of relationship via the mediation analysis (Hayes, 2009; Hayes, 2013).

\section{Method}

\subsection{Data Collection and Measurement}

A survey questionnaire was administered to local employees of a MNC in Vietnam. The surveys were distributed through the internal mail system of the firm. This survey was explained to target employees two weeks before its implementation by expatriates, and then researchers visited the MNC in Vietnam to monitor whether the surveys were properly implemented and to have focus group interviews with local employees for deeper understanding of the results. Out of 250 local employees in the MNC, 143 returned a useable survey (an effective response rate of 57 percent). The variables measured in the survey are: perceived career growth opportunities (CGO), organizational commitment (OC), and turnover intentions (TO). In addition to the perceived CGO, OC, and TO, demographic and other variables were asked such as age group, gender, education level, and position.

The perceived CGO was assessed using the scale initially developed by Bedeian, Kemery, \& Pizzolatto (1991). This scale was also used in Nouri \& Parker (2013), and it has been known to have high reliability and validity. The survey participants quantified the degree of agreement to various questionnaire items such as: "I believe that my current job has helped my growth in my career" and "My present job is relevant to growth and development in my career." Responses ranged from one (strongly disagree) to six (strongly agree) in a 6-point Likert-type scale.

The OC was assessed by the scale adopted by Rhoades, Eisenberger, \& Armeli, S. (2001). 


\section{Macrothink}

International Journal of Human Resource Studies

ISSN 2162-3058

2019, Vol. 9, No. 4

The survey participants responded OC-related questionnaire items such as "I feel a strong sense of belonging to my organization," "Working at my organization has a great deal of personal meaning to me," and "I really feel that problems faced by my organization are also my problem." Participants indicated the extent to which they agree with each item on the 6-point Likert-type scale from one (strongly disagree) to six (strongly agree).

The TO was assessed by the 3-item turnover intention subscale developed by Crossley, Bennett, Jex, \& Burnfield (2007) and the questionnaire items were "I intend to leave this organization soon," "I plan to leave this organization in the next little while," and "I may leave this organization before too long." These items were also measured by the 6-point Likert-type scale.

\subsection{Analytics Procedure}

For descriptive purpose, the Pearson's correlations were calculated among the three numeric variables (CGO, OC, and TO), and the sample means and SDs of the three numeric variables were summarized by the demographic and other control variables such as age, gender, education, and position. For mediation analysis, we considered the model represented in Figure 1 (Baron \& Kenny, 1986; Hayes 2013). To quantify the mediation of OC from CGO to $\mathrm{TO}$, linear regression models were used: $\mathrm{OC}=\kappa_{0}+\kappa_{1} \mathrm{CGO}$ and $\mathrm{TO}=\gamma_{0}+\gamma_{1} \mathrm{CGO}+\gamma_{2} \mathrm{OC}$. Under these models, $\kappa_{1}$ quantifies the difference in the expected OC score when we compare two subjects with one score difference in CGO, $\gamma_{1}$ quantifies the difference in the expected TO score associated with one score difference in CGO by controlling OC, and $\gamma_{2}$ quantifies the difference in the expected TO score associated with one score difference in OC given the same CGO score. By this mediation analysis, we can better understand the magnitude of the potential causal path from CGO to TO, that is $\beta_{1}=\kappa_{1} \gamma_{2}+\gamma_{1}$ in the simple linear regression model TO $=\beta_{0}+\beta_{1} \mathrm{CGO}$.
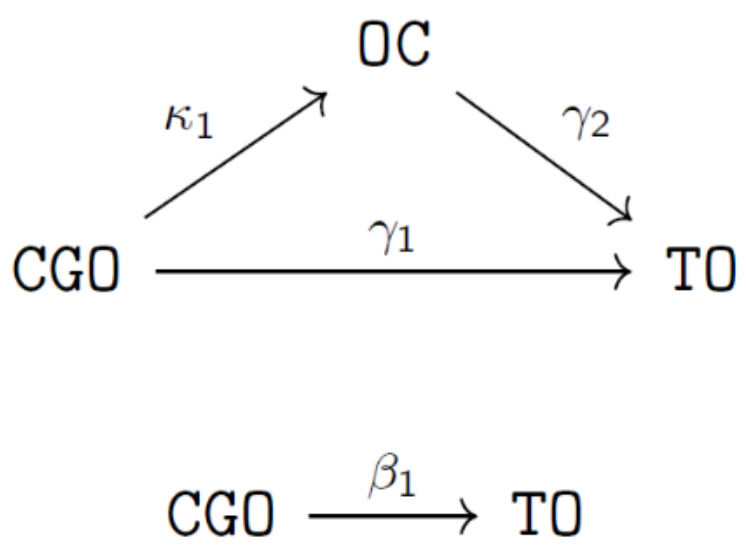

Figure 1. Graphical description of the statistical models of the mediation analysis

To formally test and quantify the indirect effect (i.e., $\kappa_{1} \gamma_{2}$ ), a bootstrapping method was used (Preacher \& Hayes, 2004, Preacher \& Hayes, 2008). Bootstrap samples were taken 5,000 times, and a bias corrected $95 \%$ confidence interval (CI) was calculated. This nonparametric 


\section{Macrothink}

is known to be appropriate for the mediation analysis with a small sample size (Preacher and Hayes 2004, Preacher and Hayes 2008), and it is a recommended practice for the mediation analysis (Hair, Hult, Ringle, \& Sarstedt, 2014). Hayes 2004, Hayes 2013).

\section{Results}

In the analysis, we noticed that one subject input one for all of the questionnaire items. After removing this outlier, the sample size was $n=142$. As shown in Figure 2 and Table 1, we observed a positive correlation between CGO and OC $(\mathrm{r}=.70, \mathrm{p}<.0001)$, a negative correlation between CGO and TO $(\mathrm{r}=-.49, \mathrm{p}<.0001)$, and a negative correlation between OC and TO $(r=-.48, \mathrm{p}<.0001)$.
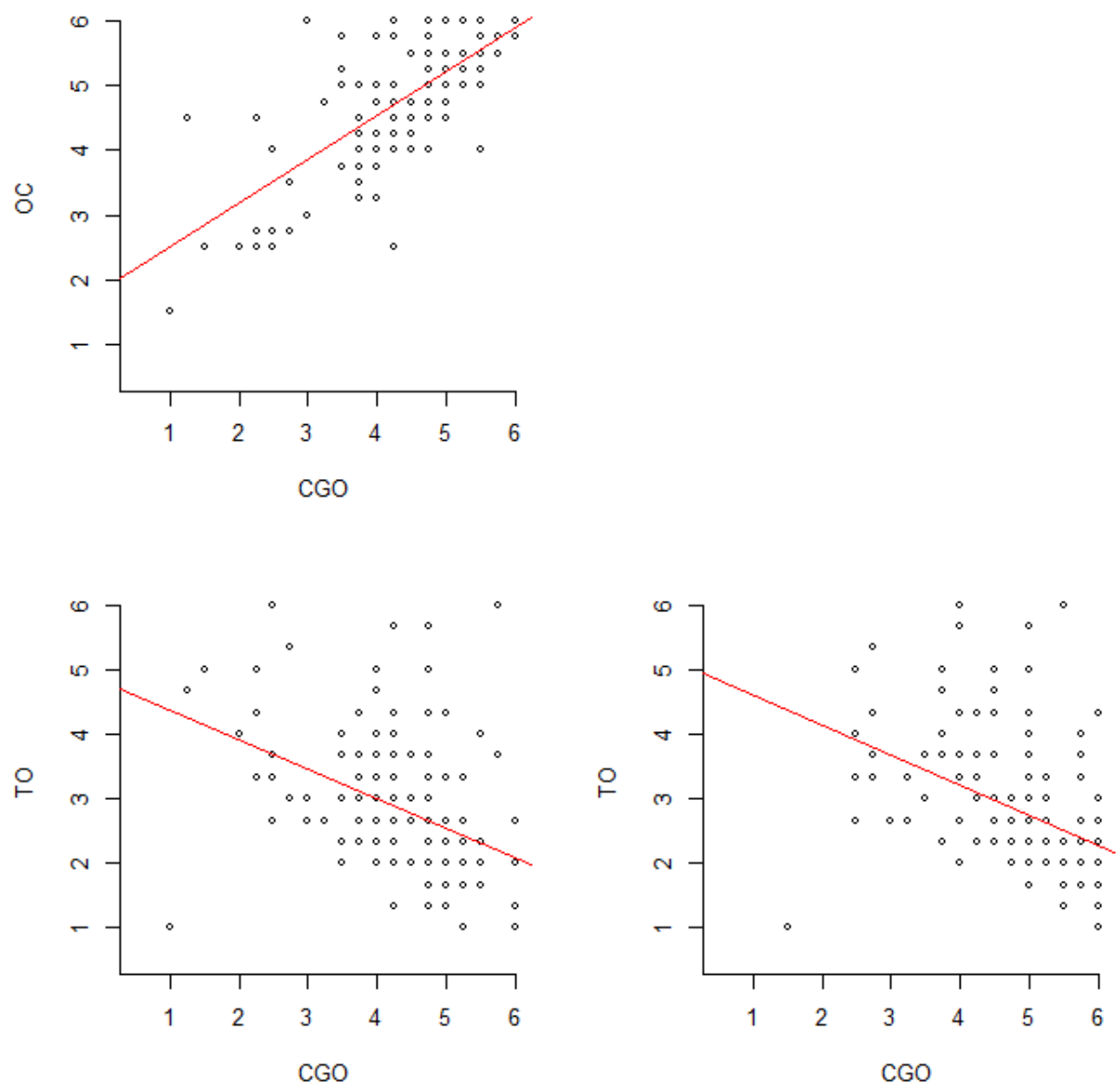

Figure 2. Pairwise scatter plots among CGO, OC, and TO and estimated regression lines 
Table 1. Estimated Pearson's correlations among CGO, OC, and TO scores

\begin{tabular}{cccc}
\hline & CGO & OC & TO \\
\hline CGO & 1 & - & - \\
OC & .698 & 1 & - \\
TO & -.495 & -.483 & 1 \\
\hline
\end{tabular}

As shown in Table 2, TO decreased with respect to age, and CGO was lower among the middle age groups (25-39) when compared to the other age groups (20-24 and 40-49). There were no remarkable differences in $\mathrm{CGO}, \mathrm{OC}$, and $\mathrm{TO}$ between the two genders and among the education groups. The high school group demonstrated relatively high CGO, OC, and TO, but the sample size was only $\mathrm{n}=2$ in the group. The CGO and OC seemed to be higher among managers $(\mathrm{n}=30)$ and directors $(\mathrm{n}=2$ only) when compared to team members $(\mathrm{n}=$ 99) and team leaders $(n=11)$.

Table 2. Descriptive statistics of CGO, OC, and TO scores by the demographic/other variables (mean and SD in parentheses)

\begin{tabular}{llllll}
\hline Variable & Level & $\mathrm{n}$ & $\mathrm{CGO}$ & $\mathrm{OC}$ & $\mathrm{TO}$ \\
\hline Age & $20-24$ & 16 & $4.52(0.56)$ & $4.64(0.64)$ & $3.00(0.88)$ \\
& $25-29$ & 63 & $4.37(1.04)$ & $4.71(1.00)$ & $3.02(1.17)$ \\
& $30-34$ & 44 & $4.36(1.02)$ & $4.98(0.80)$ & $2.73(1.03)$ \\
& $35-39$ & 13 & $4.21(1.23)$ & $4.63(1.21)$ & $2.69(0.87)$ \\
& $40-44$ & 3 & $4.75(0.66)$ & $5.33(0.58)$ & $2.33(0.58)$ \\
& $45-49$ & 3 & $4.67(0.38)$ & $5.83(0.29)$ & $1.44(0.19)$ \\
\hline Education & Male & 77 & $4.31(0.87)$ & $4.69(0.94)$ & $2.85(1.02)$ \\
& Female & 65 & $4.47(1.10)$ & $4.96(0.89)$ & $2.86(1.14)$ \\
& High School & 2 & $5.12(0.88)$ & $5.12(0.88)$ & $3.17(0.71)$ \\
& College & 15 & $4.37(1.24)$ & $4.73(1.22)$ & $2.82(1.34)$ \\
& Undergraduate & 116 & $4.37(0.95)$ & $4.82(0.89)$ & $2.86(1.06)$ \\
& Graduate & 9 & $4.36(1.05)$ & $4.81(0.88)$ & $2.70(0.96)$ \\
\hline Position & Team Member & 99 & $4.31(0.94)$ & $4.68(0.93)$ & $2.91(1.06)$ \\
& Team Leader & 11 & $4.16(1.64)$ & $4.91(1.25)$ & $2.70(1.35)$ \\
& Manager & 30 & $4.67(0.80)$ & $5.17(0.62)$ & $2.82(0.99)$ \\
& Director & 2 & $4.88(0.18)$ & $5.75(0.35)$ & $1.50(0.24)$ \\
\hline
\end{tabular}

Under the model $\mathrm{OC}=\kappa_{0}+\kappa_{1} \mathrm{CGO}$, the parameter $\kappa_{1}$ was estimated as .65 with $95 \% \mathrm{CI}$ 
$(.54, .77)$ and $\mathrm{p}$-value $<.0001$. Under the model $\mathrm{TO}=\gamma_{0}+\gamma_{1} \mathrm{CGO}+\gamma_{2} \mathrm{OC}$, the parameter $\gamma_{1}$ was estimated as -.33 with $95 \% \mathrm{CI}(-.55,-.12)$ and $\mathrm{p}$-value $=.0013$, and $\gamma_{2}$ was estimated as -.31 with $95 \% \mathrm{CI}(-.54,-.08)$ and $\mathrm{p}$-value $=.0042$. Under the model $\mathrm{TO}=\beta_{0}+\beta_{1} \mathrm{CGO}$, the parameter $\beta_{1}$ was estimated as -.54 with $95 \%$ CI $(-.70,-.38)$ and $\mathrm{p}$-value $<.0001$. The parameter estimations and statistical significances are summarized in Table 3.

Table 3. Estimated model parameters for the statistical models

\begin{tabular}{llllll}
\hline \multicolumn{5}{l}{ Unstandardized coefficients } & \multicolumn{2}{l}{ Standardized coefficients } \\
\hline$\kappa_{0}$ & Estimate & $95 \% \mathrm{CI}$ & Estimate & $95 \% \mathrm{CI}$ & p-value \\
$\kappa_{1}$ & 1.949 & $(1.45,2.45)$ & .000 & $(-.12, .12)$ & - \\
$\gamma_{0}$ & .654 & $(.54, .77)$ & .698 & $(.58, .82)$ & $<.0001$ \\
$\gamma_{1}$ & 5.817 & $(4.99,6.64)$ & .000 & $(-.14, .14)$ & - \\
$\gamma_{2}$ & -.334 & $(-.55,-.12)$ & -.307 & $(-.51,-.11)$ & .0013 \\
$\beta_{0}$ & -.311 & $(-.54,-.08)$ & -.268 & $(-.47,-.07)$ & .0042 \\
$\beta_{1}$ & 5.210 & $(4.50,5.92)$ & .000 & $(-.14, .14)$ & - \\
\hline
\end{tabular}

From the bootstrapping method, the total effect and the direct effect of CGO on TO were estimated as -.538 with $\mathrm{p}<.01$ and -.334 with $\mathrm{p}<.01$, and the indirect effect (through the mediator OC) was estimated as -.204 with a $95 \%$ bias-corrected CI of $(-.406,-.066)$. These statistical results suggest that $\mathrm{OC}$ is a partial mediator in the relationship between CGO and TO.

Table 4. Mediation effect of organizational commitment on perceived career growth opportunity - turnover intention relationship

\begin{tabular}{cccccc}
\hline & & \multicolumn{3}{c}{ Indirect Effect } \\
\cline { 4 - 6 } $\begin{array}{c}\text { Independent } \\
\text { Variable }\end{array}$ & Total Effect & Direct Effect & Point Estimate & \multicolumn{2}{c}{ BC 95\% CI } \\
\cline { 4 - 7 } & & & & Lower & Upper \\
\hline CGO & $-.538(\mathrm{p}<.01)$ & $-.334(\mathrm{p}<.01)$ & -.204 & -.4064 & -.0663 \\
\hline
\end{tabular}

\section{Discussion}

\subsection{Theoretical Contributions}

In order to carry out management localization, hiring and retaining local employees are necessary for MNC's local responsiveness. A majority of MNCs retain a large percentage of their personnel and production operation, and they research and develop capability in their home country (UNCTAD, 2003). The recruitment of local managers is motivated by a global core competency, a diversity of strategic perspective, or a multicultural frame of reference 
among the top management team (Harvey \& Buckley, 1997). However, there have been numerous reports of the continuing trend of high turnover rate among local employees in MNCs.

MNCs always face significant challenges in local markets, and frequent changes in employees add burdens to these challenges. To address these challenges, particularly to retain their employees in a sustainable way, MNCs can adopt management localization. Despite increasing practices of management localization, only few researchers have studied its effectiveness in an empirical approach apart from professional reports. In this study, we quantified the relationship between the perceived career growth opportunity (CGO) and turnover intentions (TO) through organizational commitment (OC) as a mediating variable in an MNC. We observed that, even adjusting for TO, the relationship between CGO and TO was statistically significant. In other words, though OC is an important factor leading to TO which is a well-known result, According to our results, CGO seems an important factor related to TO other than a path through OC. More specifically, the total linear association between CGO and TO (i.e., $\beta_{1}$ in Figure 1) was estimated as -.538 , and the adjusted linear association (i.e., $\gamma_{1}$ after adjusting OC in Figure 1) was -.334, near two-thirds in magnitude. This finding can make a contribution to international HRM and development field.

An opinion poll from HR professionals in Hong Kong, Malaysia, and Singapore showed a unanimous view that the rampant "job hopping" in these Asian countries have been a culture and a typical attitude among Asian employees (Khatri, Fern, \& Budhwar, 2001). This attitude can lead to a lack of bond to their organization, and it can eventually lead to low job performances and high turnover intentions. According to our result, abundant career growth opportunities are related to both organizational commitment and turnover intention (through a different reason than organizational commitment). To this end, this article enlightens the importance of perceived career growth opportunities for both reasons in management field when it comes to finding out an important factor leading to turnover intention in MNCs.

\subsection{Limitations and Future Directions}

Despite the significant results discussed above, this article has limitations that should be noted. First, the primary date for the research came from a single source, making it possible that common-method variance inflated relationships between variables Podsakoff, MacKenzie, Lee, \& Podsakoff (2003).. Although the use of a single-factor test may provide an indication of whether the factor accounts for all of the covariances among the items, this procedure actually does nothing to statistically control for method effects (Podsakoff et al., 2003). For the next study, it is recommended for researchers to use multiple sources to prove given relationships.

Second, the data were collected in a single organization, so it could not fully capture the career growth opportunities due to normative influence of a single organizational culture (Davis-Blake \& Pfeffer, 1989). If we could obtain data from multiple organizations, we could estimate the relationships among perceived career growth opportunities, organizational commitment, and turnover intentions by accounting for organization-to-organization variance. 
In order to better understand the relations among the three variables, we needed to observe other key confounding variables such as pay, organizational climate, and other factors which could be strongly associated with employees' retention as well. In addition, a longitudinal study will be helpful to monitor the changes in these confounding variables and the changes in CGO, OC, and TO simultaneously.

\subsection{Practical Implications}

To leverage advantages in globalized competition, many MNCs are aware of the importance of hiring and retaining competent employees in the marketplace as well as many local employees (Carmeli, 2004). There are not rich empirical-based studies for factors which can affect local employees' retention, especially internal variables such as individual attitudes, values, and behaviors. This study can help employers of MNCs better understand the relationship between career growth opportunity and turnover intentions and seek potential solution of high turnover rates.

As a final note, in the focus group interviews in target companies affiliated with the MNC, many expatriates have believed a low salary is one of main reasons for turnovers among local employees. A majority of the expatriates strongly agreed that local employees leave because of less earnings than they could earn in other companies. However, this study demonstrated that a low salary may not be the only reason, but a lack of career growth opportunities is tied with turnover intention.

\section{Conclusion}

A high turnover rate has been recognized as an important factor to be managed rather than just to be minimized. Salary has been identified as a primary factor of turnover based on our qualitative data from the focus group interviews, and it has been a well-known factor. Furthermore, an increase in salary requires a huge amount of resource in a large corporation. Instead, MNCs can look beyond other determinants of turnover intentions such as career growth opportunity and organizational commitment. Based on our quantitative data obtained from the survey, we found that a lack of career growth opportunity is also significantly related to a higher turnover intention, and it is partially mediated by a lower level of organizational commitment.

\section{References}

Alam, A., \& Asim, M. (2019). Relationship between job satisfaction and turnover intention. International Journal of Human Resources Studies, 9(2), 163-194. https://doi.org/10.5296/ijhrs.v9i2.14618

Al-khrabsheh, A., Abo-Murad, M., \& Bourini, I. (2018). Effect of organizational factors on employee turnover intention: An empirical study of academic professionals at Jordanian government universities. International Journal of Human Resource Studies, 8(2), 164-177. https://doi.org/10.5296/ijhrs.v8i2.12847

Allen, N. J., \& Meyer, J. P. (1996). Affective, continuance, and normative commitment to the organization: An examination of construct validity. Journal of Vocational Behavior, 49, 
252-276. https://doi.org/10.1006/jvbe.1996.0043

Arnold, H. J., \& Feldman D. C. (1982). A multivariate analysis of the determinants of turnover. Journal of Applied Psychology, 67, 350-360. https://doi.org/10.1037/0021-9010.67.3.350

Arthur, M. B. (2008). The Hughes award-examining contemporary careers: A call for interdisciplinary inquiry. Human Relations, 61, 163-186. https://doi.org/10.1177/0018726707087783

Aselage, J., \& Eisenberger, R. (2003). Perceived organizational support and psychological contracts: a theoretical integration. Journal of Organizational Behavior, 24, 491-509. https://doi.org/10.1002/job.211

Baron, R. M., \& Kenny, D. A. (1986). The moderator-mediator variable distinction in social psychological research: Conceptual, strategic, and statistical considerations. Journal of $\begin{array}{llrl}\text { Personality and Social } & \text { Psychology, } & \text { 51(6), } & \text { 1173-1182. }\end{array}$ https://doi.org/10.1037/0022-3514.51.6.1173

Bedeian, A, Kemery, E., \& Pizzolatto, A. (1991). Career commitment and expected utility of present job as predictors of turnover intentions and turnover behavior. Journal of Vocational Behavior, 39, 331-43. https://doi.org/10.1016/0001-8791(91)90042-K

Blau, P. (1964). Justice in social exchange. Sociological Inquiry, 34, 193-206. https://doi.org/10.1111/j.1475-682X.1964.tb00583.x

Bloom, M., \& Michel, J. G. (2002). The relationships among organizational context, pay dispersion, and managerial turnover. Academy of Management Journal, 45, 33-42. https://doi.org/10.2307/3069283

Carmeli, A. (2004). The link between organizational elements, perceived external prestige and performance. Corporate Reputation Review, 6, 314-331. https://doi.org/10.1057/palgrave.crr.1540002

Cavanaugh, M. A., \& Noe, R. A. (1999). Antecedents and consequences of relational components of the new psychological contract. Journal of Organizational Behavior, 20, 323-340.

https://doi.org/10.1002/(SICI)1099-1379(199905)20:3<323::AID-JOB901>3.0.CO;2-M

Chay Y. W., \& Aryee, A. (1999). Potential moderating influences of career growth opportunities on careerist orientation and work attitudes. Journal of Organizational Behavior, 20 , 613-623. https://doi.org/10.1002/(SICI)1099-1379(199909)20:5<613::AID-JOB979>3.0.CO;2-A

Chung, C., \& Furusawa, M. (2015). The HRM of foreign MNCs operating in Europe. In M. Dickmann, C. Brewster, \& P. Sparrow (Eds.), International Human Resource Management: Contemporary Issues in Europe (3ed.). London: Routledge.

Coff, R. W. (1997). Human assets and management dilemmas: Coping with hazards on the 
road to resource-based theory. Academy of Management Review, 22, 374-402. https://doi.org/10.5465/amr.1997.9707154063

Cohen, A. (1993). Organizational commitment and turnover: A meta-analysis. Academy of Management Journal, 36, 1140-1157. https://doi.org/10.5465/256650

Cohen, A. (2007). Commitment before and after: an evaluation and reconceptualization of organizational commitment. Human Resource Management Review, 17, 336-354. https://doi.org/10.1016/j.hrmr.2007.05.001

Crossley, C. D., Bennett, R. J., Jex, S. M., \& Burnfield, J. L. (2007). Development of a global measure of job embeddedness and integration into a traditional model of voluntary turnover. Journal of Applied Psychology, 92, 1031-1042. https://doi.org/10.1037/0021-9010.92.4.1031

Davis-Blake, A., \& Pfeffer, J. (1989). Just a mirage: The search for dispositional effects in organizational research. Academy of Management Review, 14, 385-400. https://doi.org/10.5465/amr.1989.4279071

DeConinck, J., \& Bachmann, D. (2005). An analysis of turnover among retail buyers. Journal of Business Research, 58, 874-882. https://doi.org/10.1016/j.jbusres.2003.10.009

Dowling, P., \& Welch, D. (2004). International Human Resource Management: Managing People in a global context (4th ed.). London: Thomson Learning.

Fayol-Song, L. (2001). The Reasons behind management localization: A Case Study of China. Journal of Asia Pacific Business Review, 17(4), 455-471. https://doi.org/10.1080/13602381.2010.546642

Fields, D. (2002). Taking the measure of work: a guide to validated scales for organizational research and diagnosis. Thousand Oaks: Sage. https://doi.org/10.4135/9781452231143

Granrose, C., \& Baccili, P. A. (2006). Do psychological contracts include boundaryless or protean careers? Career Development International, 11(2), 163-182. https://doi.org/10.1108/13620430610651903

Griffeth, R. W., Hom, P. W., \& Gaertner, S. (2000). A meta-analysis of antecedents and correlates of employee turnover: Update, moderator tests, and research implications for the next millennium. Journal of Management, 26, 463-488. https://doi.org/10.1177/014920630002600305

Hailey, J. (1993). Localisation and expatriation: the continuing role of expatriates in developing countries. Cranfield Achool of Management Working Paper Series, SWP 18/93.

Hair J. F., Hult, G. T. M., Ringle, C., \& Sarstedt, M. (2014). A Primer on Partial Least Squares Structural Equation Modeling (PLS-SEM). Thousand Oaks, CA: Sage Publications, Inc.

Harvey, M. G., \& Buckley, M. R. (1997). Managing inpatriates: Building a global core competency. Journal of World Business, 32, 32. https://doi.org/10.1016/S1090-9516(97)90024-9 
Harzing, A. W. (2001). An analysis of the functions of international transfer of managers in MNCs. Employee Relations, 23, 581-98. https://doi.org/10.1108/01425450110409248

Hayes, A. F. (2009). Beyond Baron and Kenny: Statistical mediation analysis in the new millennium. Communication Monographs, 408-420. https://doi.org/10.1080/03637750903310360

Hayes, A. F. (2013). Methodology in the social sciences. Introduction to mediation, moderation, and conditional process analysis: A regression-based approach. Guilford Press, New York, NY.

Hertel, G, Geister, C, \& Konradt, U. (2005). Managing virtual teams: a review of current empirical research. Human Resource Management Review, 15, 69-95. https://doi.org/10.1016/j.hrmr.2005.01.002

Hollenbeck, J. R., \& Williams, C. R. (1986). Turnover functionality versus turnover frequency: A note on work attitudes and organizational effectiveness. Journal of Applied Psychology, 71, 606-611. https://doi.org/10.1037/0021-9010.71.4.606

Homans, G. (1974). Social Behavior. New York: Harcourt Brace Jonvanovich.

Huselid, M. (1995). The impact of human resource management practices on turnover, productivity, and corporate financial performance. Academy of Management Journal, 38, 635-672. https://doi.org/10.2307/256741

Ito, J. K., \& Brotheridge, C. M. (2005). Does supporting employees' career adaptability lead to commitment, turnover, or both.? Human Resource Management, 44, 5-19. https://doi.org/10.1002/hrm.20037

Joo, B. K., \& Park, S. (2009). Career satisfaction, organizational commitment and turnover intention. Leadership and Organizational Development Journal, 31(6), 482-500. https://doi.org/10.1108/01437731011069999

Khatri, N., Fern, C. T., \& Budhwar, P. (2001). Explaining employee turnover in an Asian context. Human Resource Management Journal, 11(1), 54-74. https://doi.org/10.1111/j.1748-8583.2001.tb00032.x

Kraimer, M. L., Seibert, S. E., Wayne, S. J., Liden, R. C., \& Bravo, J. (2011) Antecedents and outcomes of organizational support for development: The critical role of career opportunities. Journal of Applied Psychology, 96(3), 485-500. https://doi.org/10.1037/a0021452

Lambert, E. G., Hogan, N. L., \& Barton, S. M. (2001). The impact of job satisfaction on turnover intent: A test of a structural measurement model using a national sample of workers. Social Science Journal, 38, 233-250. https://doi.org/10.1016/S0362-3319(01)00110-0

Lee, C. H., \& Bruvold, N. T. (2003). Creating value for employees: investment in employee development. International Journal of Human Resource Management, 14(6), 981-1000. https://doi.org/10.1080/0958519032000106173

Li, P. S. (2008). World migration in the age of globalization: Policy implications and 
challenges. Halifax, NS: Atlantic Metropolis Centre.

Maertz, C. P., \& Campion, M. A. (2004). Profiles in quitting: Integrating process and content turnover theory. Academy of Management Journal, 47, 566-582. https://doi.org/10.2307/20159602

Masterson, S. S., Lewis, K., Goldman, B. M., \& Taylor, M. S. (2000). Integrating justice and social exchange: The differing effects of fair procedures and treatment on work relationships. Academy of Management Journal, 43(4), 738-748. https://doi.org/10.2307/1556364

Mathieu, J. E. (1991). A cross-level nonrecursive model of the antecedents of organizational commitment and satisfaction. Journal of Applied Psychology, 76, 607-618. https://doi.org/10.1037/0021-9010.76.5.607

Mathieu, J. E., \& Zajac, D. M. (1990). A review and meta-analysis of the antecedents, correlates, and consequences of organizational commitment. Psychological Bulletin, 108(2), 171-194. https://doi.org/10.1037/0033-2909.108.2.171

Mauer, T. J., \& Tarulli, B. A. (1994). Investigation of perceived environment, perceived outcome, and person variables in relationship to voluntary development activity by $\begin{array}{lllll}\text { employees. Journal of } & \text { Applied } & \text { Psychology, } & \text { 79, }\end{array}$ https://doi.org/10.1037/0021-9010.79.1.3

Meyer J. P., \& Allen, N. J. (1997). Commitment in the workplace: Theory, research, and application. Thousand Oaks, CA: Sage.

Meyer, J. P., \& Allen, N. J. (1984). Testing the "side-bet theory" of organizational commitment: Some methodological considerations. Journal of Applied Psychology, 69, 372-378. https://doi.org/10.1037/0021-9010.69.3.372

Meyer, J. P., \& Allen, N. J. (1991). A three-component conceptualization of organizational commitment. Human Resource Management Review, 1(1), 61-89. https://doi.org/10.1016/1053-4822(91)90011-Z

Mobley, W. H. (1982). Some unanswered questions in turnover and withdrawal research. Academy of Management Review, 7(1), 111-116. https://doi.org/10.5465/amr.1982.4285493

Morrow, P. (1993). The theory and measurement of work commitment. Greenwich: Jay Press Ltd.

Mowday, R. T., Koberg, C. S., \& McArthur, A. W. (1984). The psychology of the withdrawal process: A cross-validational test of Mobley's intermediate linkages model of turnover in two samples. Academy of Management Journal, 27, 79-94. https://doi.org/10.2307/255958

Nouri, H., \& Parker, R. J. (2013). Career growth opportunities and employee turnover intentions in public accounting firms. The British Accounting Review, 45(2), 138-148. https://doi.org/10.1016/j.bar.2013.03.002

Oh, I. S., Kim, K., Darnold, T. C., Hwang, J. O., Yoo, T. Y., Park, Y. A., et al. (2007). Relationships among job satisfaction, organizational commitment, job performance, and 
turnover intention: A literature review and meta-analysis with Korean samples. Korean Journal Management, 15(4), 43-86.

Podsakoff, P. M., MacKenzie, S. B., Lee, J. Y., \& Podsakoff, N. P. (2003). Common method biases in behavioral research: a critical review of the literature and recommended remedies. Journal of Applied Psychology, 88, 879-903. https://doi.org/10.1037/0021-9010.88.5.879

Porter, L. W., \& Steers, R. M. (1973). Organizational, work, and personal factors in employee turnover and absenteeism. Psychological Bulletin, 80, 151-176. https://doi.org/10.1037/h0034829

Preacher, K. J., \& Hayes, A. F. (2004). SPSS and SAS procedures for estimating indirect effects in simple mediation modes. Behavior Research Methods, Instruments, \& Computers, 36, 717-731. https://doi.org/10.3758/BF03206553

Preacher, K. J., \& Hayes, A. F. (2008). Asymptotic and resampling strategies for assessing and comparing indirect effects in multiple mediator models. Behavior Research Methods, 40, 879-891. https://doi.org/10.3758/BRM.40.3.879

Randall, D. (1990). The consequences of organizational commitment: methodological investigation. Journal of Organizational Behavior, 11, 361-378. https://doi.org/10.1002/job.4030110504

Reiche, B. S. (2008). The configuration of employee retention practices in multinational corporations foreign subsidiaries. International Business Review, 17(6), 676-687. https://doi.org/10.1016/j.ibusrev.2008.09.004

Reiche, S. (2007). The effect of International Staffing practices on subsidiary staff retention in multinational corporations. International Journal of Human Resource Management, 18(4), 523-536. https://doi.org/10.1080/09585190601178711

Reichers, A. E. (1985). A review and reconceptualization of organizational commitment. Academy of Management Review, 10, 465-476. https://doi.org/10.5465/amr.1985.4278960

Riketta, M. (2002). Attitudinal organizational commitment and job performance: A metaanalysis. Journal of Organizational Behavior, 23, 257-266. https://doi.org/10.1002/job.141

Rosenzweig, P. (2006). The dual logics behind international human resource management: pressures for global integration and local responsiveness. In G. Stahl \& I. Björkman (Ed.), Handbook of Research in International Human Resource Management, Cheltenham: Edward Elgar.

Rupp, D. E., \& Cropanzano, R. (2002). The mediating effects of social exchange relationships in predicting workplace outcomes from multifoci organizational justice. Organizational Behavior and Human Decision Processes, 89(1), 925-946. https://doi.org/10.1016/S0749-5978(02)00036-5

Shaw, J. D., Delery, J. E., Jenkins, G. D., \& Gupta, N. (1998). An organization-level analysis of voluntary and involuntary turnover. Academy of Management Journal, 41, 511-525. 
https://doi.org/10.2307/256939

Simonsen, P. (1997). Promoting a development culture in your organization. Palo Alto, CA: Davies-Black.

Sinem, A., \& Baris, A. (2011). The effect of transformational leadership behavior on organizational culture: An application in pharmaceutical industry. International Review of Management and Marketing, 1(3), 65-73.

Sturges, J., Guest, D., \& Davey, K. M. (2000). Who’s in charge? Graduates' attitudes to and experiences of career management and their relationship with organizational commitment. European Journal of Work and Organizational Psychology, 9(3), 351-370. https://doi.org/10.1080/135943200417966

Tett, R. P., \& Meyer, J. P. (1993). Job satisfaction, organizational commitment, turnover intention, and turnover: Path analyses based on meta-analytic findings. Personnel Psychology, 46, 259-293. https://doi.org/10.1111/j.1744-6570.1993.tb00874.x

Toh, S. M., \& DeNisi, A. S. (2003). Host country national reactions to expatriate pay policies: a model and implications. Academy of Management Review, 4, 606-621. https://doi.org/10.5465/amr.2003.10899387

UNCTAD. (2003). World Investment Report 2003: FDI policies for development: National and international perspectives. Geneva: UNCTAD.

Wright, P. M., \& Kehoe, R. R. (2007). Human resource practices and organizational commitment: A deeper examination (CAHRS Working Paper \#07-15). Ithaca, NY: Cornell University, School of Industrial and Labor Relations, Center for Advanced Human Resource Studies.

Zheng, C., \& Lamond, D. (2009). A critical review of human resource management studies (1978-2007) in the People's Republic of China. International Journal of Human Resource Management, 20(11), 2194-2227. https://doi.org/10.1080/09585190903239609

\section{Copyright Disclaimer}

Copyright for this article is retained by the author(s), with first publication rights granted to the journal.

This is an open-access article distributed under the terms and conditions of the Creative Commons Attribution license (http://creativecommons.org/licenses/by/4.0/). 